\title{
CURRENT PRACTICE WITH REGARD TO SHORT-TERM INCENTIVE SCHEMES FOR MIDDLE MANAGERS
}

\author{
CHRISILLA GRIGORIADIS \\ CGrigoriadis@cellc.co.za \\ MARK BUSSIN \\ Department of Human Resource Management \\ University of Johannesburg
}

\begin{abstract}
This study aimed to determine what the current practice is with regard to short-term incentive schemes for middle managers. This was done by means of a quantitative study through a structured research survey completed by a sample of forty-eight organisations. The design elements, performance measures and payout practices of the various schemes in use were surveyed, as well as the participants' view on the perceived effectiveness of their short-term incentive schemes. Evidence shows that the majority of organisations have a short-term incentive scheme in place for middle managers, and that the type of scheme used in most of the organisations is a performance-related bonus scheme, introduced mainly to drive business performance and reward superior performance.
\end{abstract}

Key words

Incentives schemes, scheme effectiveness, middle management

\section{Background to the study}

The use of pay-for-performance, and in particular the use of incentive schemes has increased dramatically since 1987 in Fortune 1000 corporations (Lawler, 2003), and in a recent survey of reward practices conducted by WorldatWork, it was reported that approximately $66 \%$ of companies in the United States use variable pay beyond their executive levels. This is an increase from 59\% in 1995 (Wilson, 2003).

Historically, high-performing employees could expect to receive bigger salary increases than their lower-performing peers, especially when annual merit increases were averaging higher as a result of increasing inflation, but today, it has become increasingly more difficult to differentiate between the salaries of individual employees based on high or low performance. In order to supplement these merit increases, many companies have started implementing pay-for-performance incentive schemes (Orens and Elliot, 2002).

There is thus globally a trend towards implementing performance-based incentive schemes, and in particular an increase in the use of incentive schemes for employees other than executives. In South Africa, variable pay and in particular incentive schemes have been implemented successfully for executives and sales staff across organisations, whereas most often, middle managers do not reap the benefits of such incentive programmes.

The focus of this study therefore was to determine what the current practice is with regard to short-term incentive schemes for middle managers, as very little empirical research has been done in this regard. Short-term incentive schemes in particular are defined as incentive schemes where the measurement period is around one year and payments are in cash e.g. profit share, gain share, commission and bonus scheme (Bussin, 2003). Commission schemes were, however, excluded from this study as they are mainly used for sales employees, and a need existed to determine what the incentive scheme practices are with regard to non-sales middle management employees.

Middle managers are considered to be those employees at around the Paterson D-Band level. When looking at a traditional hierarchical organisation, middle managers are those employees below senior managerial level and above the supervisory or junior management level. The professional specialists often fall into this employee category.
Motivation/rationale for the study

There is a lack of empirical research and literature on the problem, and a pressing need in the market exists for this research. The reasons for focusing on middle managers are that they are often the group of employees where little emphasis is placed on the manner in which their rewards are structured. This research has aimed to address this knowledge gap with specific reference to the South African market.

\section{Literature on short-term incentive schemes}

The literature on short-term incentive schemes is contradictory. There are proponents as well as sceptics to be found in the literature. Research has more often than not found that incentives do not motivate people or have a significant positive impact on their performance (Kohn, 1993), but it can be argued that a lack of sufficient rewards or dissatisfaction with the current reward system does tend to demotivate people and have a negative effect on their performance (Thorpe \& Homan, 2000). It is thus critical to "get it right" as regards to incentives, as a shortfall in this area is likely to have negative consequences if not applied correctly.

There is ample evidence though that result-based incentive schemes, especially at the individual level, can greatly increase company performance (Gerhart \& Rynes, 2003). In research done by Bussin and Huysamen (2004), it was also found that the short-term incentive policy was also one of the areas that had the greatest positive impact in private organisations. Shortterm incentives are thus a strong area of focus in organisations, and specifically when amending the organisation's remuneration policy. Bussin and Huysamen (2004) found that a change in the short-term incentive policy in private; parastatal and public sector organisations was one of the top five changes in order of extent of change that changed most in the remuneration policy.

There is some research to be found in the literature with regard to the factors or design principles that need to be taken into consideration when designing and implementing an incentive scheme. There is, however, substantial literature available on the dynamics of executive and sales incentive schemes (Gerhart \& Rynes, 2003), and much research has been published on what is considered best practice with regard to incentive schemes for executives and sales employees, but very little research has focused on middle managers (Scott, McMullen, Wallace \& Morajda, 2004). 
According to Freher (2002), the annual incentive scheme has the greatest potential to influence individual behaviour and enhance business results. A properly designed annual incentive scheme can assist organisations in achieving the desired performance based on critical tactical success factors. He is also of the opinion that an individual manager sees selection to an annual incentive scheme as a key step on his/her career ladder, and that participation in such a scheme has considerable monetary as well as symbolic value. He emphasises further though, that a line of sight for inclusion into a management incentive programme is critical. In other words, participation should only extend to individuals who can truly influence (directly or as a significant member of a team) the planned performance measures.

Research done by Döckel, Basson and Coetzee (2006) shows that compensation has a strong significant relation to organisational commitment - specifically for high-technology employees. Sutherland (2004) has established in her research that incentives/bonuses and/or variable pay are the fifth most important item considered by knowledge workers when considering to stay or leave their current organisation. Bloedorn, also (2002) asserts that incentives can expand the team committed to delivering results and that they can cause employees, individually and collectively, to focus their attention on the company's goals and identify with shareholder interests.

The literature encourages organisations to take eligibility for incentive schemes deeper down into their organisations (Bloedorn, 2002), but it provides no or very little guidelines to that effect.

\section{Objectives of the study}

The value-add of this research will firstly be theoretical, as it will influence thinking about short-term incentive schemes, and will build towards a theory or framework with regard to short-term incentives for middle managers. Secondly, the value of this research will be practical in the sense that the research will highlight the current practices in short-term incentive schemes, and this will provide organisations with a way forward with which to implement these schemes at middle management level.

It is anticipated that, through this research, organisations will be alerted to what the design elements are that make up a short-term incentive scheme for middle managers. It should, however, be pointed out that this research has identified certain current practice elements, but it is critical that when organisations design short-term incentive schemes for middle managers that they customise the incentive scheme to fit their individual business' needs, which is what a large organisation did as part of their becoming one of the best companies to work for (Van Dyk \& Herholdt, 2004).

\section{RESEARCH DESIGN}

\section{Research Approach}

This was an empirical study. A quantitative research methodology was followed and the research was conducted by means of a cross-sectional, explorative survey. Survey research is a method of quantitative research whereby "a sample of a chosen population can be studied to discover the relative incidence, distribution, and interrelations of sociological and psychological variables" (Kerlinger \& Lee, 2000, p. 599)

In this research a sample of forty eight organisations was studied with respect to their short-term incentive schemes for middle management. Survey research is well suited to a problem such as this, as it is an economical and accurate manner in which a great deal of information can be gathered from a large population (Kerlinger \& Lee, 2000).

\section{Research Methodology}

Participants/respondents

The research questionnaire was sent out to all the organisations (about five thousand) on the database of a large South African remuneration consulting firm.

As this was an existing population being surveyed, the sampling strategy can be considered to be accidental or convenience sampling (Kerlinger \& Lee, 2000).

Forty-eight organisations participated in this study. The research questionnaires were completed by the person who is primarily responsible for the remuneration and reward management function at each participating organisation. These respondents were identified as human resources and reward professionals; CEO's and finance managers. The research questionnaire was completed by respondents from a variety of industry sectors. The classification and definition of the industry sectors used were those normally used by the remuneration consultancy whose database of organisations was surveyed. The industry sectors of the participating organisations can be seen in Table 1 .

TABLE 1

Participating ORganisations: Industry SeCtor

\begin{tabular}{lc}
\hline Industry Sector & Percentage of Participants \\
\hline Producer Services & $27 \%$ \\
Transformative & $23 \%$ \\
Distributive Services & $17 \%$ \\
Other (mostly Information Technology) & $13 \%$ \\
Social Services & $10 \%$ \\
Extractive & $8 \%$ \\
Personal Services & $2 \%$ \\
\hline
\end{tabular}

The largest group of the participating organisations is in the producer services sector, which are typically organisations in banking and financial services; insurance; real estate; engineering; accounting; consulting; legal services; and miscellaneous business services.

The workforce size of the various participating organisations can be seen in Table 2 .

TABLE 2

Participating ORganisations: WORKForCe SIZE

\begin{tabular}{lc}
\hline Industry Sector & Percentage of Participants \\
\hline Less than 150 & $17 \%$ \\
$150-500$ & $25 \%$ \\
$501-2000$ & $25 \%$ \\
$2001-10000$ & $23 \%$ \\
10001 plus & $10 \%$ \\
\hline
\end{tabular}

The range of the workforce size of the participating organisations is quite wide, as it includes both very large and quite small organisations. In Table 3 , the descriptive statistics relating to the various organisations' workforce sizes can be viewed. 
TABLE 3

Participating organisations: WORKFORCE SIZE DESCRIPTIVE STATISTICS

\begin{tabular}{lc}
\hline Descriptive Statistic & Value \\
\hline Mean & 3797 \\
Median/50th Percentile & 1164 \\
Standard Deviation & 7446 \\
Minimum & 32 \\
Maximum & 42769 \\
Range & 42737 \\
25th Percentile & 223 \\
75th Percentile & 3269 \\
Skewness & 3,65 \\
Kurtosis & 16,1 \\
\hline
\end{tabular}

Measuring instrument/methods of data gathering.

The measuring instrument used in this study was a structured research questionnaire. A suitable questionnaire was developed and then piloted with a small sample of reward experts and academics before being sent out to the research participants.

Job evaluation correlation tables were included in the questionnaires to participants; to allow the participants to complete the questionnaire with reference to the correct employee group. It was made clear that the category of staff this research applied to was middle managers.

The questionnaire contained both factual items exploring the short-term incentive schemes in use by organisations, as well as perceived- effectiveness questions. The basis for these perceived effectiveness questions were aspects that are usually considered by remuneration professionals as important in establishing the effectiveness of their schemes. A Likert scale was used for these questions. A Likert scale is also known as a summative rating scale that requires the respondent to respond to several statements that are clearly favourable or unfavourable concerning the topic being measured (Elmes, Kantowitz \& Roediger III, 1999).

Open-ended questions were also included in the questionnaire to generate authentic responses from participants. Data from the questionnaires was further supplemented by follow-up telephonic interviews where necessary, to enhance the quality of the data collected.

Statistical analysis/treatment of the data.

The response data from the questionnaires circulated was the source for data analysis, as well as any follow-up telephonic interviews. Descriptive statistics are the primary method by which the factual data is portrayed. This reflects the research results visually, and is a suitable method of data analysis, as the sample of research participants is limited.

A secondary analysis was done on the participating organisations' size and industry sector, to determine whether there was in fact a relationship between the participating organisations' biographical data and the various elements researched in the survey. No significant trends were however found between the participating organisations' biographical data and the other elements researched in this survey.

Where there was an opportunity to provide a free-text response, these responses were examined to establish the similarities to responses provided by other participants. These responses were used in determining common areas of difficulties experienced by organisations, and common areas of advice for other organisations about to embark on the use of short-term incentive schemes for their middle managers.

\section{RESULTS}

The specific areas explored by this survey were shortterm incentive schemes in use by the participating organisations at middle management level with respect to the design elements, performance measures, payout practices as well as the effectiveness of these schemes as perceived by the respondents.

Of the forty eight organisations surveyed, $77 \%$ indicated that they had a short-term incentive scheme in place for their middle managers, while $23 \%$ of the respondents had no such scheme in place. The organisations that did not have a short-term incentive scheme in place were questioned about their reasons for not having such a scheme. Table 4 reflects their responses.

TABLE 4

REASONS WHY PARTICIPATING ORGANISATIONS DO NOT HAVE A SHORT-TERM INCENTIVE SCHEME FOR MIDDLE MANAGERS

\begin{tabular}{lc}
\hline Reasons for not introducing a scheme & Percentage \\
\hline $\begin{array}{l}\text { The organisation has considered it, and we will start } \\
\text { implementing short-term incentive schemes for middle } \\
\text { managers in the near future }\end{array}$ & $55 \%$ \\
$\begin{array}{l}\text { Other (more information is required on incentive schemes, } \\
\text { and there are limited resources to implement these schemes) }\end{array}$ & $27 \%$ \\
$\begin{array}{l}\text { There is no need for short-term incentive schemes for middle } \\
\text { managers in our organisation }\end{array}$ & $9 \%$ \\
$\begin{array}{l}\text { The organisation uses other reward/recognition schemes to } \\
\text { incentivise our middle managers }\end{array}$ & $9 \%$
\end{tabular}

More than half the organisations have considered implementing short-term incentive schemes and may start implementing them for middle managers in the near future. The organisations that do have a short-term incentive scheme in place for their middle managers were asked to indicate what the reasons were that they considered in introducing the scheme. Their responses are reflected in Table 5.

TABLE 5

REASONS FOR INTRODUCING A SHORT-TERM INCENTIVE SCHEME FOR MIDDLE MANAGERS

\begin{tabular}{lc}
\hline Reasons for introducing the STI & $\begin{array}{c}\text { Percentage of respondents who } \\
\text { agreed with the statement }\end{array}$ \\
\hline To drive business performance & $97,3 \%$ \\
To reward superior performance & $91,9 \%$ \\
To improve employee motivation & $78,4 \%$ \\
To increase retention & $70,3 \%$ \\
To drive business strategy & $64,9 \%$ \\
To communicate goals and objectives & $44,4 \%$ \\
To share wealth & $43,2 \%$ \\
To address a particular business issue & $29,7 \%$ \\
\hline
\end{tabular}

The two main reasons for introducing a short-term incentive scheme at middle management level are to drive business performance, and to reward superior performance.

Of the $77 \%$ of participants that have a short-term incentive scheme in place, the majority (89\%) of organisations have only one short-term incentive scheme in place for their middle 
managers, while only $11 \%$ have two schemes in place. As regards the type of scheme the organisation used, the results are reflected in Table 6 .

TABLE 6

TYPES OF SHORT-TERM INCENTIVE SCHEME USED BY PARTICIPATING ORGANISATIONS

\begin{tabular}{lc}
\hline Type of scheme in use & $\begin{array}{c}\text { Percentage of organisations using the particular } \\
\text { short-term incentive scheme }\end{array}$ \\
\hline Bonus Scheme & $84 \%$ \\
Profit-sharing Scheme & $14 \%$ \\
Gain-sharing Scheme & $3 \%$ \\
Other STI & $8 \%$ \\
\hline
\end{tabular}

The definitions of these short term incentive schemes were provided in the questionnaires and are the definitions normally used by the remuneration consultancy whose database of organisations was surveyed. Bonus schemes are defined as usually having between 4 and 7 measures which are carefully chosen to drive business strategy. These targets are typically quantitative and qualitative in nature and are usually expressed as threshold (budget), target and stretch target.
Gainsharing is typically a company wide, formula based scheme for lower level staff aimed primarily at improving productivity. It differs from profit sharing in that it has measures and employees lower down can control and exclude items in the income statement like tax, depreciation, bad debt and other economic factors that might influence profit. In a Profit share scheme, the bonus is a predetermined percentage of the organisation's profits, usually also dependant on the achievement of other objectives as well.

Only the data for the participants using bonus schemes will be reported in this article. There are very few organisations using profit-sharing (14\%); gain-sharing (3\%), and other short-term incentive schemes $(8 \%)$

\section{Eligibility}

In most cases, all the middle managers in the organisations were eligible to participate in the scheme. Twenty two per cent of organisations involved the eligible employees in the design and development of the scheme, and where the eligible employees fell under a bargaining unit, only $14 \%$ of organisations involved key stakeholders from the bargaining unit in the development and design of the scheme. Where eligible employees were however involved, this happened mostly through a committee or forum where some of the eligible employees would be present. This is a significant

TABLE 7

RESPONSIBLE PERSON(s) FOR THE VARIOUS DESIGN ELEMENTS IN A BONUS SCHEME

\begin{tabular}{|c|c|c|c|c|c|c|c|c|}
\hline $\begin{array}{l}\text { Bonus Scheme design } \\
\text { elements }\end{array}$ & $\begin{array}{l}\text { Remuneration } \\
\text { Manager }\end{array}$ & $\begin{array}{l}\text { Human } \\
\text { Resources }\end{array}$ & Line Management & Finance & $\begin{array}{c}\text { Remuneration } \\
\text { Consultants }\end{array}$ & CEO & $\begin{array}{l}\text { Other (Committee } \\
\text { of Remuneration; } \\
\text { HR and Line }\end{array}$ & $\begin{array}{c}\text { Other } \\
\text { (Remco and } \\
\text { Board) }\end{array}$ \\
\hline Development and design & $22 \%$ & $13 \%$ & - & - & $9 \%$ & $27 \%$ & $16 \%$ & $13 \%$ \\
\hline Initial implementation & $34 \%$ & $28 \%$ & $13 \%$ & $6 \%$ & $3 \%$ & - & $16 \%$ & - \\
\hline Communication & $22 \%$ & $34 \%$ & $16 \%$ & $3 \%$ & - & $13 \%$ & $12 \%$ & - \\
\hline Day-to-day Administration & $22 \%$ & $46 \%$ & $13 \%$ & $13 \%$ & - & - & $6 \%$ & - \\
\hline Reviewing the scheme & $37 \%$ & $16 \%$ & - & $3 \%$ & $3 \%$ & $19 \%$ & $6 \%$ & $16 \%$ \\
\hline
\end{tabular}

finding, as it is critical to the success of the scheme to involve eligible employees in the design of the scheme (Thorpe \& Homan, 2000).

Responsibilities with regard to short-term incentive schemes Participating organisations were questioned as to who the primary person(s) are who is (are) responsible for the design; initial implementation; communication; administration and reviewing of their short-term incentive schemes. The results as displayed in Table 7 are applicable to bonus schemes only, as this is the scheme which $84 \%$ of the organisations have in place in their organisations.

From Table 7, it is clear that many of the responsibilities relating to the design elements of short-term incentives are largely Human Resources and Remuneration responsibilities.

Forty seven percent of organisations review their bonus scheme once a year and $44 \%$ review the scheme as and when required. Fifty nine percent of respondents have had the bonus schemes in their organisations in existence for longer than three years.

\section{Performance measures}

As can be seen in Table 8, sixty percent of responding organisations use between three and five performance criteria or performance measures in their bonus scheme. They have indicated that the nature of these performance criteria can be quantitative, qualitative, financial, or non-financial, although in the majority of cases a financial measurement is involved.
The number and type of performance measures used in a scheme is significant as this influences the middle manager's ability to achieve these targets and receive a payout (Gerhart \& Rynes, 2003), (Pfeffer and Sutton, 2006) and (Freher, 2002).

TABLE 8

NUMBER OF PERFORMANCE MEASURES THAT NEED TO BE MET, BEFORE A PAYOUT CAN BE MADE

\begin{tabular}{lc}
\hline $\begin{array}{l}\text { Average number of measures } \\
\text { in bonus scheme }\end{array}$ & $\begin{array}{c}\text { Percentage of respondents having this } \\
\text { number of measures in their scheme }\end{array}$ \\
\hline 0 & $3 \%$ \\
1 & $10 \%$ \\
2 & $10 \%$ \\
3 & $20 \%$ \\
4 & $33 \%$ \\
5 & $7 \%$ \\
6 & $3 \%$ \\
8 & $3 \%$ \\
9 & $3 \%$ \\
11 & $3 \%$ \\
12 & $3 \%$ \\
Grand Total & $100 \%$
\end{tabular}


In $59 \%$ of the cases, these performance criteria are set by the top management of the organisation, followed by the departmental manager in conjunction with the individual employee (22\%). The primary method by which compliance with these performance criteria is measured is by means of a performance management system (69\%).

In $88 \%$ of the organisations, a certain performance criterion, referred to as a trigger, needs to be met first before the bonus scheme can pay out. This is usually the financial performance of the company, followed by the requirement that the individual employee and the department must achieve certain performance goals.

\section{Payouts on the scheme}

The payouts in the bonus scheme are funded from the organisation budget. Payout on the scheme is, however, not guaranteed as certain performance measures need to be achieved first. Sixty nine per cent of organisations using a bonus scheme have indicated that these schemes pay out once a year.

Participants were questioned about the various proportions that certain performance measures contribute towards a $100 \%$ payout on the bonus scheme. The ranges in each group of performance measures ranged from $0 \%-100 \%$ for each category, and the ranges where the majority of participants responded, are indicated in Table 9. Due to the wide range of responses reflected, the results should be interpreted with care.

TABLE 9

Proportional contribution of Performance measures TOWARDS PAYOUT ON A BONUS SCHEME

\begin{tabular}{lcc}
\hline $\begin{array}{l}\text { Type of performance } \\
\text { measures }\end{array}$ & $\begin{array}{c}\text { Proportional } \\
\text { contribution towards } \\
\text { a 100\% payout on } \\
\text { the scheme }\end{array}$ & $\begin{array}{c}\text { Percentage of } \\
\text { respondents who } \\
\text { indicated in this } \\
\text { range }\end{array}$ \\
\hline Group wide/organisation measures & $20 \%-50 \%$ & $38 \%$ \\
Business unit/division measures & $25 \%-40 \%$ & $64 \%$ \\
Individual performance measures & $30 \%-60 \%$ & $70 \%$ \\
\hline
\end{tabular}

There is thus a heavier proportional contribution of individual performance measures, than group wide or organisation measures at middle management level. The line of sight for middle managers to contribute towards the organisational success measures, e.g. profit is less than it might be for senior executives. The individual performance measures are thus more heavily weighted as these can be influenced directly by the middle managers.

Seventy five per cent of organisations cap their payout in the bonus scheme at a certain percentage or amount. Participants were requested to supply actual payout figures for 2004, 2005 and 2006. Due to the wide range of responses (from $0 \%-200 \%$ of the individual employee's guaranteed annual package), the median payouts were calculated. The results are depicted in Table 10, and should again be interpreted with care.
TABLE 10

Payouts of bouns SChemes in 2004-2006

\begin{tabular}{lccc}
\hline & 2004 & 2005 & 2006 \\
\hline $\begin{array}{l}\text { Median payout per year as a \% of } \\
\text { total guaranteed package }\end{array}$ & $12 \%$ & $11 \%$ & $9 \%$ \\
$\begin{array}{l}\text { Mean payout per year as a \% of total } \\
\text { guaranteed package }\end{array}$ & $30 \%$ & $28 \%$ & $18 \%$ \\
$\begin{array}{l}\text { Ranges of payouts per year as a \% } \\
\text { of total guaranteed package }\end{array}$ & $0 \%-200 \%$ & $4 \%-87 \%$ & $0 \%-115 \%$ \\
\hline
\end{tabular}

\section{Perceived effectiveness dimensions}

The participants were requested to rate twenty perceived effectiveness dimensions with regard to the shortterm incentive schemes in their organisations on a Likert scale that ranged from strongly disagree (1), to strongly agree (5). They were requested to respond as to how they currently perceive the scheme. The mean responses were also calculated.

A reliability statistic of Chronbach's Alpha was calculated at 0,901 . Chronbach's Alpha is used to assess the internal consistency reliability of an instrument that has different scoring and response scales, such as a Likert Scale (Kerlinger \& Lee, 2000). The instrument used here to assess the perceived effectiveness of short-term incentive schemes thus has a high internal consistency. The instrument is reliable, and the items can be considered homogeneous.

The actual percentage of the participants' responses to the significant items on the scale is reflected in Table 11, and is sorted according to the highest mean responses.

Common difficulties experienced with the schemes, and advice to organisations about to embark on the implementation of short-term incentive schemes

Participants were asked to indicate what difficulties they were currently experiencing with their short-term incentive schemes in their respective organisations. Their responses were free-text to encourage authentic responses. Some of the responses are summarised in Table 12 .

Finally, participants were questioned as to what they would recommend to organisations about to embark on a short-term incentive scheme. Some of their responses, which were free-text, are summarised in Table 13.

The participating organisations seem to experience common areas of difficulties when implementing short-term incentive schemes and their advice to other organisations concern the prevention of some of the difficulties that they themselves have experienced. 
TABLE 11

PerCeIVEd EFFeCtIVENESS OF SHORT-TERM INCENTIVE SCHEMES

\begin{tabular}{|c|c|c|c|c|c|c|}
\hline Item & $\begin{array}{l}\text { Mean } \\
\text { Response }\end{array}$ & $\begin{array}{l}\text { Strongly } \\
\text { Disagree }\end{array}$ & Disagree & Neither Agree & $\begin{array}{c}\text { Agree } \\
\text { nor Disagree }\end{array}$ & Strongly Agree \\
\hline $\begin{array}{l}\text { The scheme has a positive influence on individual performance } \\
\text { targets and goals }\end{array}$ & 3,92 & $2,8 \%$ & $8,3 \%$ & $5,6 \%$ & $61,1 \%$ & $22,2 \%$ \\
\hline $\begin{array}{l}\text { The scheme has a positive influence on company/organisation } \\
\text { performance targets and goals }\end{array}$ & 3,89 & $2,8 \%$ & $5,6 \%$ & $8,3 \%$ & $66,7 \%$ & $16,7 \%$ \\
\hline The scheme drives positive behavioural performance & 3,61 & $2,8 \%$ & $8,3 \%$ & $22,2 \%$ & $58,3 \%$ & $8,3 \%$ \\
\hline $\begin{array}{l}\text { The scheme results in an increase in employee morale over the long } \\
\text { term }(4 \text { months }+)\end{array}$ & 3,61 & $2,8 \%$ & $8,3 \%$ & $22,2 \%$ & $58,3 \%$ & $8,3 \%$ \\
\hline $\begin{array}{l}\text { The scheme is effective in motivating participating employees to } \\
\text { reach the required performance measures }\end{array}$ & 3,61 & $2,8 \%$ & $8,3 \%$ & $22,2 \%$ & $58,3 \%$ & $8,3 \%$ \\
\hline The participating employees buy-into the scheme & 3,61 & $2,8 \%$ & $8,3 \%$ & $22,2 \%$ & $58,3 \%$ & $8,3 \%$ \\
\hline $\begin{array}{l}\text { The current performance management system supports the short- } \\
\text { term incentive scheme }\end{array}$ & 3,61 & $5,6 \%$ & $22,2 \%$ & $2,8 \%$ & $44,4 \%$ & $25,0 \%$ \\
\hline $\begin{array}{l}\text { Employees feel that they can achieve the performance measures } \\
\text { that have been set }\end{array}$ & 3,5 & $5,6 \%$ & $8,3 \%$ & $19,4 \%$ & $63,9 \%$ & $2,8 \%$ \\
\hline $\begin{array}{l}\text { The short-term incentive scheme is able to differentiate significantly } \\
\text { between poor performing and high-performing employees }\end{array}$ & 3,5 & $8,3 \%$ & $19,4 \%$ & $13,9 \%$ & $30,6 \%$ & $27,8 \%$ \\
\hline The participating employees have no disputes with regard to the scheme & 3,44 & $0,0 \%$ & $19,4 \%$ & $25,0 \%$ & $47,2 \%$ & $8,3 \%$ \\
\hline $\begin{array}{l}\text { The employees who participate in the scheme experience the } \\
\text { scheme positively }\end{array}$ & 3,36 & $0,0 \%$ & $22,2 \%$ & $27,8 \%$ & $41,7 \%$ & $8,3 \%$ \\
\hline $\begin{array}{l}\text { The scheme results in an increase in employee morale over the } \\
\text { short term (1- } 3 \text { months) }\end{array}$ & 3,36 & $0,0 \%$ & $22,2 \%$ & $27,8 \%$ & $41,7 \%$ & $8,3 \%$ \\
\hline The participating employees perceive the scheme as fair & 3,36 & $0,0 \%$ & $22,2 \%$ & $27,8 \%$ & $41,7 \%$ & $8,3 \%$ \\
\hline $\begin{array}{l}\text { The scheme results in increased teamwork amongst participating } \\
\text { employees }\end{array}$ & 3,36 & $0,0 \%$ & $16,7 \%$ & $36,1 \%$ & $41,7 \%$ & $5,6 \%$ \\
\hline It is relatively easy to set performance measures for the scheme & 3,33 & $2,8 \%$ & $16,7 \%$ & $33,3 \%$ & $38,9 \%$ & $8,3 \%$ \\
\hline $\begin{array}{l}\text { The short-term incentive scheme is able to create sufficient wealth } \\
\text { for high performing employees }\end{array}$ & 3,22 & $13,9 \%$ & $16,7 \%$ & $16,7 \%$ & $38,9 \%$ & $13,9 \%$ \\
\hline The scheme serves as an effective retention tool & 3,14 & $5,6 \%$ & $22,2 \%$ & $30,6 \%$ & $36,1 \%$ & $5,6 \%$ \\
\hline The scheme attracts high talent for the organisation & 3,08 & $5,6 \%$ & $22,2 \%$ & $38,9 \%$ & $25,0 \%$ & $8,3 \%$ \\
\hline $\begin{array}{l}\text { Participation in the scheme leads to unhealthy competition among the } \\
\text { participating employees }\end{array}$ & 2,22 & $22,2 \%$ & $44,4 \%$ & $22,2 \%$ & $11,1 \%$ & $0,0 \%$ \\
\hline
\end{tabular}

\section{TABLE 12}

COMMON DIFFICULTIES EXPERIENCED WITH SHORT-TERM INCENTIVE SCHEMES

Benchmarking and obtaining accurate competitor information

Developing and determining objective performance criteria or measures, and having an objective performance management system - which is a prerequisite for an incentive scheme

Determining the weighting of company; team and the individual performance measures

The limited funds available, that in turn prohibit the payment of a bonus

Even though bonuses aren't guaranteed, employees start to see them as a

13 th cheque (something they are entitled to) - they therefore do not want to have to perform to earn a bonus

It is very hard to give the "bad news" when there is no bonus

Participating employees perceive the scheme as being subjective and unfair, and they don't trust the schem

The scheme is often poorly communicated

Line managers don't understand the scheme

TABLE 13

\section{Advice to organisations ABout to EMbark ON SHORT-TERM} INCENTIVE SCHEMES

Do a proper benchmarking and analysis

Obtain board and CEO buy-in (also line manager buy-in)

Consultation with participating employees (focus groups) to get their buy-in Ensure that a proper performance management system is in place and that it is applied consistently

Have clear rules that are properly communicated and consistently applied Get the performance measures in the scheme right and hold firm onto them. Don't keep moving the goalposts. The scheme will lose its credibility Communicate performance regularly during the assessment period

Be clear about what behaviours you are incentivising, as you may get what you pay for

Keep it simple. Use the scheme as a reward system and not as a system to manage the business

Tailor-make incentives (allow for flexibility and choice)

Be transparent in the allocation process

Consider having a moderation process in place

Track consistency and fairness of the system

\section{DISCUSSION}

This study aimed to determine the short-term incentive practices at middle management level with regard to the type of schemes used, their design elements, performance measures and payout practices. Their perceived effectiveness by the respondents was also measured.

The move towards implementing short-term incentive schemes for middle managers is gaining popularity as $77 \%$ of the organisations surveyed already had at least one such scheme in place. Of the other $23 \%$ of the organisations that do not have a short-term incentive scheme in place, $55 \%$ cited that they have considered it and that they may start implementing short-term incentive schemes in the near future.

The two main reasons for introducing short-term incentive schemes for middle management, as reflected in Table 5 , are to drive business performance $(97 \%)$ and to reward superior performance $(91.9 \%)$. A total of $78.4 \%$ of organisations also introduced the scheme to improve employee motivation. This is a large and convincing number of participants.

A recent similar study conducted in the United Kingdom reports that only $31 \%$ of respondents indicated that they introduced the scheme to "motivate \& incentivise staff" (Armstrong \& Thompson, 2006, p.26). In another survey of a similar nature conducted in the United States of America, the primary objective of the variable pay programme was to improve organisation or team financial performance (65\% of respondents) (Scott; Mcmullan; Wallace and Moradja, 2004). It appears as though we are being influenced more by the American school of thought than by the British.

Even though the literature has on numerous occasions indicated that it is critical to the success of the scheme to involve eligible employees in the design of the scheme (Thorpe \& Homan, 2000) and to increase ownership and acceptance of the scheme (Armstrong, 2002), only 22\% of the participants in this survey involve their eligible employees in the development and design 
of the scheme. This lack of involvement may lead to a lack of trust between management and employees, and Gerhart \& Rynes (2003) indicate that these schemes may well be undermined as a result of this lack of trust.

This lack of involvement, however, does not seem to be a factor of major concern to the participants as reflected in Table 11, as $50 \%$ of participants believe that the participating employees experience the scheme positively; $52 \%$ believe that participating employees perceive the scheme as being fair, $63.9 \%$ believe that the participating employees buy into the scheme; and $55.5 \%$ believe that the participating employees have no disputes with regard to the scheme. This is however the perception of the participating organisations and not the employees themselves.

This research found that a convincing number of respondents participate in bonus schemes as their scheme of choice (84\%), and that they also believe this is the most effective scheme for middle managers.

As Table 7 indicates, the function responsible for the design, implementation, communication and administration of bonus schemes is still largely a human resources and remuneration function. Very few respondents indicated that line management was responsible for the implementation (13\%), communication (16\%) and day-to-day administration (13\%) of the bonus scheme, yet they also indicated (Table 12) that a common difficulty experienced with the scheme is that line managers do not understand the scheme.

This, according to Beer and Canon (2004) can result in significant problems with implementation of the scheme that is often insufficiently acknowledged by practitioners. Organisations often underestimate the time and effort that need to be consumed by managers to implement and administer a new variable pay system (Cox, 2005).

Armstrong (2002) is of the opinion that an important element in the ideal performance-related pay model is that the responsibility and 'ownership' of the system should be assigned to line managers. Organisations should therefore consider educating their line managers to be able to understand these schemes and in turn to be able to set effective, clear and fair performance measures, and as a result, they must be able to differentiate successfully between the high- and poorperforming employees reporting into them.

\section{Performance measures and the performance management system}

Even though the most preferred performance measures are financial in nature, the participants indicated that they use quantitative, qualitative, financial, or non-financial performance measures. A combination of these is ideal for middle managers, as their ability to influence financial targets is more limited than that of the executives in their organisations. If the measures are perceived to be too far removed for individual employees to influence, the scheme's effectiveness is questionable (Gerhart \& Rynes, 2003).

As a result, middle managers and professionals are often also measured by "softer" and more qualitative performance measures (Thorpe \& Homan, 2000). Nevertheless, it is critical that incentive scheme performance measures shouldn't be too complex or difficult for the participants to understand and influence (Pfeffer and Sutton, 2006), and that a line-of-sight relationship must exist between the participants and the scheme's performance measures (Freher, 2002).

The literature is divided as regards the number of performance measures that should be used in a bonus scheme, but it is interesting to find that $60 \%$ of responding organisations in this study have between three and five performance measures that need to be achieved first before a payout can be made from the bonus scheme. This is a good number of measures to use. Not too many not to be able to achieve the targets, and not too few to make the achievement of targets too easy.

Participants responded mostly neutral as to the ease of setting accurate performance measures. However, $66.6 \%$ believe that the participating employees feel that they can achieve the performance measures that have been set. This is, however, the opinion of the respondents in this survey, and not that of the participating employees themselves.

The primary method by which these performance measures are measured is by means of a performance management system (69\%). Reliable performance data is thus a "must have" for variable pay programmes to work (Orens and Elliott, 2002). Care should be taken during the performance assessment, as not to use subjectivity (Thorpe \& Homan, 2000). A total of $69.4 \%$ of respondents in the survey believe that the current performance management system supports the short-term incentive scheme.

\section{Payouts in the bonus scheme}

In $88 \%$ of the organisations, a certain performance hurdle or moderating factor, often called a trigger, needs to be achieved first before the bonus scheme can pay out. This is usually the financial performance of the company, followed by the individual employee and the department achieving certain performance goals.

Slightly more than half $(58.4 \%)$ of respondents (Table 11), believe that the current incentive scheme is able to differentiate significantly between high and low performers. This is not ideal, as one of the main reasons to introduce a bonus scheme is to differentiate between high and low performers (Orens and Elliot, 2002).

Participants are divided in response to the question of whether the scheme is able to create sufficient wealth for highperforming employees. Rynes, Gerhart and Minette (2004) are of the opinion that the aspect of pay that will most directly motivate performance will be the extent to which pay is contingent on performance. I.e. if there is no real differentiation in pay-for-performance between high and low performers, there will be no real differentiation in their performance. The converse is also true. When pay is sharply differentiated on the basis of performance, pay is a very effective motivator indeed.

As Table 9 indicates, the majority of participants in this research use three different groups of performance measures where individual performance measures count more than group wide measures towards a hundred percent payout on the scheme. This is concurrent with Freher's (2002) recommendations that the scheme should have a proper balance among corporate, business unit, and individual performance.

This is also indicative of the line-of-sight principle, in that middle managers will have more influence over their own and their department's performance than the company's performance. It makes sense though that the company performance measure also counts towards the bonus payout, as the company needs to be performing before a performance bonus can be paid out in any event.

\section{The influence of short-term incentive schemes on} performance, motivation and retention of middle managers A total of $83.3 \%$ of respondents in this survey believe that the short-term incentive scheme has a positive influence on individual performance, and $83,4 \%$ believe the scheme will positively influence company performance. This corresponds to Gerhart \& Rynes' (2003) suggestion that there is ample evidence that results-based incentive plans can greatly increase performance. Incentives can only spark motivation if employees 
have enough information to work effectively and if other organisational systems and technologies are not main roadblocks to performance (Pfeffer and Sutton, 2006).

Seventy eight per cent of respondents in the survey introduced a short-term incentive scheme to improve employee motivation and $72.2 \%$ believe that the scheme actually motivates the employees to reach the required performance standards.

Participants are divided in their beliefs as to whether the scheme acts as an effective retention tool or whether the scheme is able to attract high talent to the organisation.

\section{A framework for short-term incentive schemes in}

\section{South Africa}

An objective of this study was to build towards a framework of current practice with regard to short-term incentive schemes for middle managers, to be able to assist remuneration practitioners in organisations. To this effect, a summary of the results of this study is indicated in Table 14 for short-term incentive schemes in general, and in Table 15 for bonus schemes in particular.

TABLE 14

\section{COMMON DESIGN ELEMENTS REGARDING SHORT-TERM INCENTIVE} SCHEMES FOR MIDDLE MANAGERS IN SOUTH AFRICA

\begin{tabular}{ll}
\hline Design element & Summary of survey responses \\
\hline $\begin{array}{l}\text { The prevalence of using short-term } \\
\text { incentive schemes for middle } \\
\text { managers }\end{array}$ & $\begin{array}{l}\text { 77\% of organisations surveyed use a } \\
\text { short-term incentive scheme for their } \\
\text { middle managers }\end{array}$ \\
$\begin{array}{l}\text { Reasons for introducing a short- } \\
\text { term incentive scheme }\end{array}$ & $\begin{array}{l}\text { To drive business performance, and to } \\
\text { reward superior performance }\end{array}$ \\
$\begin{array}{l}\text { Eligibility to participate in the } \\
\text { schemes }\end{array}$ & $\begin{array}{l}\text { All employees at middle management } \\
\text { level }\end{array}$ \\
$\begin{array}{l}\text { Involvement of participating } \\
\text { employees }\end{array}$ & Very little or none at all \\
Most commonly used scheme & Bonus scheme \\
\hline
\end{tabular}

TABLE 15

COMMON DESIGN ELEMENTS REGARDING BONUS SHEMES FOR MIDDLE MANAGERS IN SOUTH AFRICA

\begin{tabular}{|c|c|}
\hline Design Element & Survey Responses Summary \\
\hline $\begin{array}{l}\text { Responsibility for development } \\
\text { and design of bonus scheme }\end{array}$ & $\mathrm{CEO}$ and remuneration manager \\
\hline $\begin{array}{l}\text { Responsibility for initial } \\
\text { implementation of bonus scheme }\end{array}$ & $\begin{array}{l}\text { Remuneration manager and human } \\
\text { resources }\end{array}$ \\
\hline $\begin{array}{l}\text { Responsibility for communicating } \\
\text { the scheme }\end{array}$ & $\begin{array}{l}\text { Human resources and the } \\
\text { remuneration manager }\end{array}$ \\
\hline $\begin{array}{l}\text { Responsibility for day-to-day } \\
\text { administration of scheme }\end{array}$ & Human resources \\
\hline $\begin{array}{l}\text { Responsibility for reviewing the } \\
\text { scheme }\end{array}$ & Remuneration manager \\
\hline $\begin{array}{l}\text { How regularly the scheme needs } \\
\text { to be reviewed }\end{array}$ & Once a year, or when required \\
\hline $\begin{array}{l}\text { The number of performance } \\
\text { measures in the bonus scheme }\end{array}$ & $3-5$ \\
\hline $\begin{array}{l}\text { Responsibility for setting the main } \\
\text { performance measures }\end{array}$ & $\begin{array}{l}\text { Top management, followed by the } \\
\text { individual employee in conjunction } \\
\text { with department and line management }\end{array}$ \\
\hline $\begin{array}{l}\text { How these performance measures } \\
\text { are measured }\end{array}$ & Performance management system \\
\hline Funding of the scheme & Budgeted for \\
\hline $\begin{array}{l}\text { The use of triggers or moderators } \\
\text { before a payout can be made }\end{array}$ & $\begin{array}{l}\text { Company, division and individual } \\
\text { targets need to be achieved }\end{array}$ \\
\hline Frequency of payouts & Once a year \\
\hline
\end{tabular}

As $84 \%$ of the participating organisations use a bonus scheme for their middle managers, the common design elements regarding bonus schemes only are summarised in Table 15 .

Validity and reliability of the study

Although this study surveyed a relatively small sample of organisations, the size and sectors of the organisations surveyed are quite broad. The results are able to provide the reader with a perspective on what the current practices are with regard to short-term incentive schemes for middle managers. This is the first empirical study of this nature in South Africa, and the reliability of the results can be increased by replicating the study with a larger sample of organisations.

\section{Limitations of this research}

This study aimed to determine the practices with regard to short-term incentive schemes for middle managers. The middle manager category is quite broad, and with hindsight, it would have been more valuable had the individual subgrade categories been surveyed. It was hoped that the different organisation sectors and organisation sizes would have significantly different practices with regard to their shortterm incentive schemes, however, no significant differences were found.

\section{Value-add of this study}

This study has added significant value to the practice and perceptions of short-term incentive schemes for middle managers. Readers have an idea as to how other professionals in charge of these schemes experience their effectiveness, and they now have a guide with regard to the design elements/features that are inherent in short-term incentive schemes. Consulting organisations have conducted some surveys to determine certain elements of short-term incentive schemes. However, these were never empirical studies, and they didn't focus on middle managers specifically. It is hoped that this research has added to the broad body of knowledge about remuneration and reward management in South Africa.

\section{Suggestions for future research}

In this research, the participating organisations were asked to rate their perceived effectiveness of the schemes. It would be ideal if this research could be done where the participating employees themselves are asked to rate their perceived effectiveness of the scheme. Armstrong (2002) also recommends that organisations have the effectiveness of their performancerelated pay programmes evaluated by the people participating in the scheme. He advises, however, that the organisation should be prepared to take action based on these results.

Another suggestion for future research is to determine whether incentive schemes actually achieve the results that they were introduced for in the first place in organisations, namely to drive business performance; reward superior performance and improve employee motivation.

It would also be beneficial if future researchers could test the hypothesis of whether a lack of involvement by eligible employees in the development and design of bonus schemes actually leads to a lack of trust between eligible employees and the management of the organisation, and whether this has a negative effect on the scheme. The development of an effectiveness measure would also be very useful, where all the relevant effectiveness dimensions are surveyed, and some sort of standardised scoring mechanism can be used.

\section{Conclusion}

Short-term incentive schemes for middle managers is a vehicle that is mostly used to increase and reward superior performance. Only some of the participating organisations experience these schemes as effective in achieving the aims of the schemes. The most popular scheme to use at middle 
management level is a bonus scheme where there is a combination of individual; team and organisation-wide performance measures that contribute towards a payout on the scheme. The participating organisations in this research, however, still experience some difficulties when implementing these schemes. South African organisations should in future allocate significant time and effort to the planning and design of these schemes, and ensure that the majority of employees and line managers buy into the scheme and perceive the scheme as fair. The buy-in from both employees and line managers is critical if these schemes are going to succeed into future, and have the effect desired by organisations.

\section{REFERENCES}

Armstrong, M. (2002). Employee reward. (3 ${ }^{\text {rd }}$ ed.). CIPD: Wiltshire

Armstrong, M., Thompson, P. (Eds) (2006). What is happening in Bonus Schemes today: Part 2 - survey findings 2006. $e$ reward.co.uk, 42

Beer, M., Canon, M.D. (2004). The promise and peril in implementing pay-for performance. Human Resource Management, 43 (1), 3

Bloedorn, J.D. (2002). A pay-for-performance model. In Chingos,P.(Eds) Paying for Performance: A guide to compensation management. ( $2^{\text {nd }}$ ed.). John Wiley \& Sons: NY

Bussin, M. (2003). Unpublished Doctor of Commerce research report, Johannesburg: Rand Afrikaans University

Bussin, M., Huysamen, D. (2004). Factors driving changes to remuneration policy and outcomes. SA Journal of Human Resource Management, 2 (2), 45-54

Cox, A. (2005). The outcomes of variable pay systems: Tales of multiple costs and unforeseen consequences. International Journal of Human Resource Management, 16 (8), 1475-1497

Döckel, A., Basson, J.S., Coetzee, M. (2006). The effect of retention factors on organisational commitment: an
Investigation of high technology employees. SA Journal of Human Resource Management. 4 (2), 20-28

Elmes, D.G., Kantowitz, B.H., Roediger III, H.L. (1999). Research Methods in Psychology. (6 $6^{\text {th }}$ ed). Brooks/Cole: CA

Freher, E.W. (2002). Designing the annual management incentive plan. In Chingos, P. (Eds), Paying for Performance: $A$ guide to compensation management. ( $2^{\text {nd }}$ ed). John Wiley \& Sons: NY

Gerhart, B., Rynes, S.L. (2003). Compensation: Theory, Evidence, and Strategic Implications. Sage: CA

Kerlinger, F.N., Lee, H.B. (2000). Foundations of behavioural research. $4^{\text {th }}$ ed. Harcourt: Orlando

Khon, A. (1993). Why incentive plans cannot work. Harvard Business Review. HBS Press. USA: Boston

Lawler, E.E. (2003). Pay practices in Fortune 1000 Corporations. WorldatWork Journal. 12 (4)

Orens, R.M., Elliot, V.J.(2002). Variable Pay Programs: Pay for results in Chingos, P. (Eds). Paying for Performance: A guide to compensation management. ( $2^{\text {nd }}$ ed). John Wiley \& Sons: NY

Pfeffer, J., Sutton, R.I. (2006). What's wrong with pay-forperformance. Industrial Management.

Rynes, S.L., Gerhart, B., Minette, K.A. (2004). The importance of pay in employee motivation: Discrepancies between what people say and what they do. Human Resource Management. 43 (4), 381-394

Scott, D., McMullen, T.D., Wallace, M., Morajda, D. (2004). Annual cash incentives for managerial and professional employees. Worldatwork Journal. $4^{\text {th }}$ quarter

Sutherland, M.M. (2004). Factors affecting the retention of knowledge workers. Unpublished Doctor of Commerce research dissertation. Johannesburg: Rand Afrikaans University

Thorpe, R., Homan,G. (2000). Strategic Reward Systems. Prentice Hall: Great Britain

Van Dyk, L., Herholdt, J. (2004). Transforming your employment brand: The ABSA experience. Knowres Publishing:Randburg

Wilson, T.B. (2003). Innovative Reward Systems for the Changing Workplace. (2nd ed.). McGraw-Hill:NY 